\title{
Assessment of Correlation of Vitamin D Level with Coronary Artery Disease
}

\author{
Reddi Basha Saheb Shaik ${ }^{\circledR 1}$, Rondla Madhumitha ${ }^{2}$ \\ ${ }^{1}$ Assistant Professor, Department of Cardiology, Narayana Medical College \& Hospital, Chintareddy Palem, Nellore, Andhra Pradesh, India, ${ }^{2}$ Post Graduate, Department \\ of General Medicine, Narayana Medical College \& Hospital, Chintareddy Palem, Nellore, Andhra Pradesh, India.
}

\section{Abstract}

Background: Cardiovascular disease (CVD) is the leading cause of death in the developed world. The present study was conducted to assess correlation of plasma 25-Hydroxy-Vitamin D level with angiographic severity in coronary artery disease. Subjects and Methods: The present study was conducted on 120 patients of CAD. Group I were cases and group II were control. Hypertension, type II diabetes mellitus status, smoking etc. was recorded. $2 \mathrm{ml}$ of blood sample was taken from all patients and measurement of 25(OH) vit D levels was performed. Results: The mean BMI in group I was $24.6 \mathrm{~kg} / \mathrm{m}^{2}$ and $24.8 \mathrm{~kg} / \mathrm{m}^{2}$ in group II, smoking habit was seen in 78 in group I and 34 in group II, hypertension was seen in 65 in group I and 26 in group II, diabetes was seen in 52 in group I and 30 in group II, alcoholism in 36 in group I and 10 in group II, dyslipidemia was seen in 48 in group I and 15 in group II. The mean $25(\mathrm{OH})$ vitamin D in group I was $15.1 \mathrm{ng} / \mathrm{ml}$ and $19.6 \mathrm{ng} / \mathrm{ml} \mathrm{in}$ group II. The difference was significant $(\mathrm{P}<0.05)$. Maximum dyslipidemia $(80.5 \%)$ patients had low vitamin D level followed by DM, smoking, BMI, alcoholism and alcoholism. There was no correlation between risk factors and vitamin D deficiency (P>0.05). Conclusion: Authors found that in cases, vitamin D level was lowered as compared to control, however, there was no correlation between risk factors and CAD.

Keywords: Coronary Artery Disease, Dyslipidemia, Vitamin D

Corresponding Author: Rondla Madhumitha, Post Graduate, Department of General Medicine, Narayana Medical College \& Hospital, Chintareddy Palem, Nellore, Andhra Pradesh, India.

E-mail: rondlamadhumita@gmail.com

Received: 2 May 2020

Revised: 28 May 2020

Accepted: 12 June 2020

Published: 25 June 2020

\section{Introduction}

Cardiovascular disease (CVD) is the leading cause of death in the developed world. Atherosclerosis is the principal cause of myocardial infarction and accounts for majority of these deaths. ${ }^{[1]}$ The lifetime risk of developing CAD at the age of 40 is $50 \%$ for men and $33 \%$ for women. ${ }^{[2]}$

Evidence is increasingly showing that a deficiency of 25hydroxyvitamin $\mathrm{D}[25(\mathrm{OH}) \mathrm{D}]$ causes a higher risk of several cardiovascular conditions including hypertension heart failure, coronary calcification, myocardial infarction, subclinical atherosclerosis, diabetes mellitus (DM), obesity, and peripheral vascular disease. ${ }^{[3]}$ Emerging clinical data suggest a pleiotropic role of vitamin $\mathrm{D}$ in a variety of functions in humans. ${ }^{[4]}$ The discovery that most tissues in the body have a vitamin $\mathrm{D}$ receptor and that several possess the enzymatic machinery to convert the primary form of vitamin D, 25hydroxyvitamin $\mathrm{D}[25(\mathrm{OH}) \mathrm{Vit} \mathrm{D})]$ to the active form 1,25 dihydroxyvitamin $\mathrm{D}[1,25(\mathrm{OH}) 2 \mathrm{D}]$ has provided new insights into the function of this vitamin. ${ }^{[5]}$ Most tissues and cells in humans express vitamin D receptors (VDR), and vitamin $\mathrm{D}$ influences genes regulating many key cellular functions including cellular proliferation, differentiation, apoptosis, and angiogenesis. Of great interest is the role it can play in decreasing the risk of many chronic illnesses including common cancers, autoimmune diseases, infectious diseases, and cardio vascular disease. ${ }^{[6]}$ The present study was conducted to assess correlation of plasma 25-Hydroxy-Vitamin D level with angiographic severity in coronary artery disease.

\section{Subjects and Methods}

The present study was conducted in the department of Cardiology. It comprised of 120 patients of CAD according to the American College of Cardiology and the American Heart Association (ACC/AHA) joint guidelines of both genders. 120 controls were also taken. Approval for the study was obtained from institutional ethical committee. All patients were informed regarding the study and written consent was obtained. 
Data such as name, age, gender etc. was recorded. Group I were cases and group II were control. Hypertension, type II diabetes mellitus status, smoking, BMI, dyslipidemia and alcoholism etc. was recorded. A thorough clinical examination was performed. $2 \mathrm{ml}$ of blood sample was taken from all patients and measurement of $25(\mathrm{OH})$ vit D levels was performed.

\section{Results}

Table 1 shows that group I (Cases) had 70 males and 50 females and group II (Control) had 55 males and 65 females.

Table 2, Figure 1 shows that mean BMI in group I was 24.6 $\mathrm{kg} / \mathrm{m} 2$ and $24.8 \mathrm{~kg} / \mathrm{m} 2$ in group II, smoking habit was seen in 78 in group I and 34 in group II, hypertension was seen in 65 in group I and 26 in group II, diabetes was seen in 52 in group I and 30 in group II, alcoholism in 36 in group I and 10 in group II, dyslipidemia was seen in 48 in group I and 15 in group II. The difference was significant $(\mathrm{P}<0.05)$.

\begin{tabular}{lcl}
\hline \multicolumn{2}{l}{ Table 1: Distribution of patients } & \\
\hline Groups & Group I (Cases) & $\begin{array}{l}\text { Group II (Con- } \\
\text { trol) }\end{array}$ \\
Male & 70 & 55 \\
Female & 50 & 65 \\
\hline
\end{tabular}

\begin{tabular}{llll}
\hline \multicolumn{4}{l}{ Table 2: Demographic characteristics } \\
\hline Parameters & Group I & Group II & P value \\
BMI & 24.6 & 24.8 & 0.91 \\
Smoking & 78 & 34 & 0.01 \\
Hypertension & 65 & 26 & 0.02 \\
Diabetes & 52 & 30 & 0.05 \\
mellitus & & & \\
Alcoholism & 36 & 10 & 0.01 \\
Dyslipidemia & 48 & 15 & 0.01 \\
\hline
\end{tabular}

\begin{tabular}{|c|c|c|c|}
\hline Parameters & Group I & Group II & P value \\
\hline $\begin{array}{l}25 \quad(\mathrm{OH}) \\
\text { vitamin } \quad \mathrm{D} \\
\text { (Mean) }\end{array}$ & 15.1 & 19.6 & 0.02 \\
\hline
\end{tabular}

Table 3 \& Figure 2 shows that the mean $25(\mathrm{OH})$ vitamin D in group I was $15.1 \mathrm{ng} / \mathrm{ml}$ and $19.6 \mathrm{ng} / \mathrm{ml}$ in group II. The difference was significant $(\mathrm{P}<0.05)$.

[Table 4] shows that maximum dyslipidemia (80.5\%) patients had low vitamin D level followed by DM, smoking, BMI, alcoholism and alcoholism.

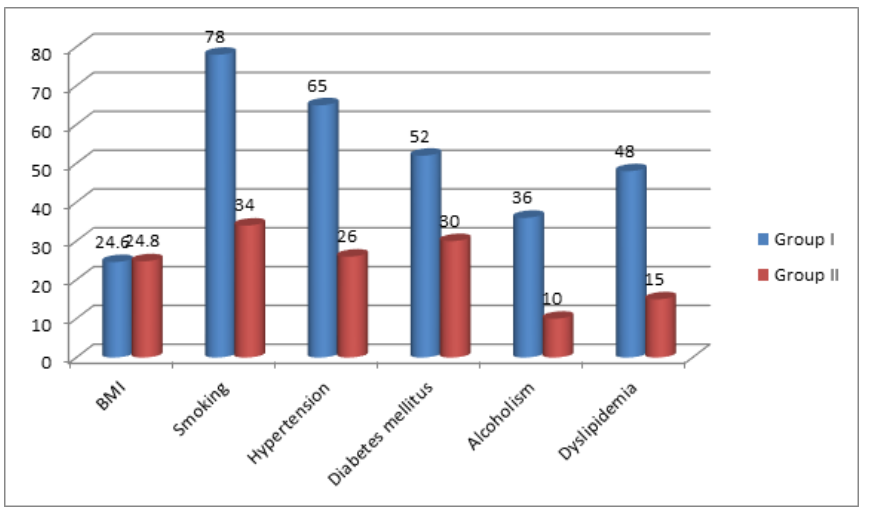

Figure 1: Demographic characteristics

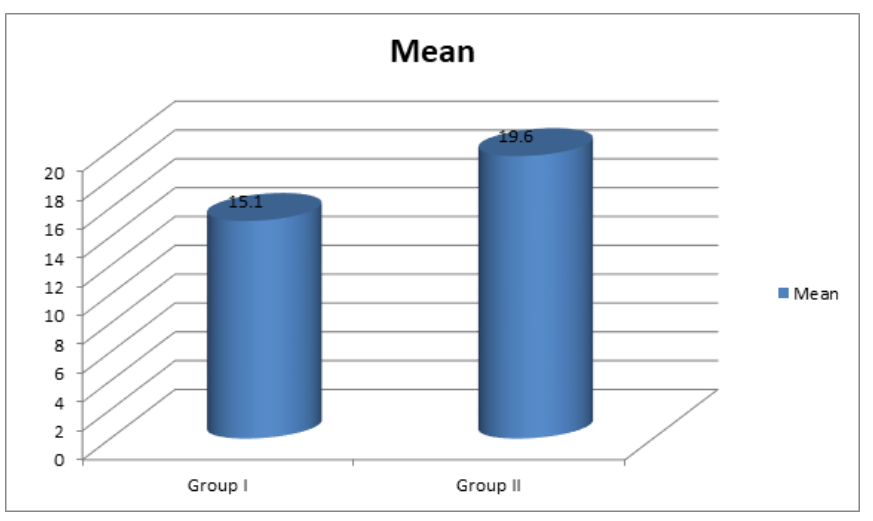

Figure 2: $25(\mathrm{OH})$ vitamin $\mathrm{D}$ level in both groups

Table 4: Prevalence of vitamin D deficiency and mean vitamin D levels in patients with different risk factors

\begin{tabular}{lll}
\hline Risk factors & $\begin{array}{l}\text { \% with vitamin } \\
\text { D deficiency }\end{array}$ & $\begin{array}{l}\text { Vitamin } \\
\text { D }\end{array}$ \\
BMean \pm SD)
\end{tabular}


Table 5: Correlation between CAD and vitamin D deficiency in both groups

\begin{tabular}{lll}
\hline Risk factors & $\mathbf{r}$ & P value \\
BMI & 0.014 & 0.81 \\
Smoking & 0.021 & 0.13 \\
Hypertension & 0.12 & 0.92 \\
Diabetes mellitus & 0.36 & 0.83 \\
Alcoholism & 0.02 & 0.72 \\
\hline Dyslipidemia & 0.017 & 0.92 \\
\hline
\end{tabular}

Table 5 shows that there was no correlation between risk factors and vitamin $\mathrm{D}$ deficiency $(\mathrm{P}>0.05)$.

\section{Discussion}

Cardiovascular disease (CVD) is the leading cause of death universally. ${ }^{[7]}$ Research has reported that low level of vitamin $\mathrm{D}$ is a risk factor for various cardiovascular disease including coronary artery disease and cardiovascular death. ${ }^{[8]}$ More recently low levels of $25(\mathrm{OH})$ Vit $\mathrm{D}$ have been linked to the presence of cardiovascular disease, hypertension, hypertension heart failure, coronary calcification, myocardial infarction, subclinical atherosclerosis, diabetes mellitus (DM), obesity, and peripheral vascular disease. Although there is no consensus on optimal levels of $25(\mathrm{OH})$ Vit D as measured in serum, vitamin $\mathrm{D}$ deficiency is defined by most experts as a $25(\mathrm{OH})$ Vit D level of less than $20 \mathrm{ng}$ per milliliter, vitamin D insufficiency as $25(\mathrm{OH})$ Vit D level of 20-30 ng per milliliter and normal vitamin $\mathrm{D}$ levels as $30-150 \mathrm{ng}$ per milliliter. ${ }^{\left[{ }^{[9]}\right.}$ The present study was conducted to assess correlation of plasma 25-Hydroxy-Vitamin D level with angiographic severity in coronary artery disease.

In present study, group I (Cases) had 70 males and 50 females and group II (Control) had 55 males and 65 females. The mean BMI in group I was $24.6 \mathrm{~kg} / \mathrm{m}^{2}$ and $24.8 \mathrm{~kg} / \mathrm{m}^{2}$ in group II, smoking habit was seen in 78 in group I and 34 in group II, hypertension was seen in 65 in group I and 26 in group II, diabetes was seen in 52 in group I and 30 in group II, alcoholism in 36 in group I and 10 in group II, dyslipidemia was seen in 48 in group I and 15 in group II. Tarcin et al conducted a study in which $25(\mathrm{OH})$ Vit D level was compared in 230 people with confirmed coronary heart disease (cases) and 70 people with normal angiogram (controls). ${ }^{[10]}$ It was found that the mean $25(\mathrm{OH})$ Vit D levels of cases and controls were calculated and they were $15.2 \pm 8.2$ and $19.9 \pm 8.7$ $\mathrm{ng} / \mathrm{mL}$ respectively. The mean $25(\mathrm{OH})$ Vit D level was higher in controls and was statistically significant $(p=0.02)$. The calculated odds ratio between cases and controls was 1.67 (C.I 0.39-4.84). There was no correlation between increasing severity of coronary artery disease with $25(\mathrm{OH})$ Vit D levels.
We found that the mean $25(\mathrm{OH})$ vitamin D in group I was $15.1 \mathrm{ng} / \mathrm{ml}$ and $19.6 \mathrm{ng} / \mathrm{ml}$ in group II. We found that maximum dyslipidemia (80.5\%) patients had low vitamin D level followed by DM, smoking, BMI, alcoholism and alcoholism. Akin et al measured 25-hydroxyvitamin D (25[OH]D) and inflammatory markers in 239 patients who underwent coronary angiography. ${ }^{[11]}$ Results showed that $83 \%$ of the study population had levels less than $30 \mathrm{ng} / \mathrm{mL}$. The Gensini score was negatively associated with serum vitamin $\mathrm{D}$ levels, and positively correlated with age, blood pressure, diabetes, hyperlipidemia and C-reactive protein levels. After adjustments for traditional and nontraditional cardiovascular risk factors, vitamin D remained a significant predictor for the severity of CAD.

We found no correlation between risk factors and vitamin $\mathrm{D}$ deficiency ( $\mathrm{P}>0.05)$. Baktur et al included a total of 113 patients undergoing coronary angiography. ${ }^{[12]}$ In total, $44.2 \%$ of the patients had NSTEMI and the remaining had STEMI. 25(OH) D levels were significantly lower in the group with a high SX score than in the group with a low SX score. Correlation analysis showed a significant correlation between $25(\mathrm{OH}) \mathrm{D}$ levels and the SX score. Multiple linear regression (MLR) analysis was used to determine the significance of the relationship between the SX score and $25(\mathrm{OH}) \mathrm{D}$, parathyroid hormone, and C-reactive protein levels and eGFR. MLR analysis revealed that only $25(\mathrm{OH}) \mathrm{D}$ levels was significantly associated with the severity of CAD.

\section{Conclusion}

Authors found that in cases, vitamin D level was lowered as compared to control, however, there was no correlation between risk factors and CAD.

\section{References}

1. Targher G, Bertolini L, Padovani R, Zenari L, Scala L, Cigolini $\mathrm{M}$, et al. Serum 25-hydroxyvitamin D3 concentrations and carotid artery intima-media thickness among type 2 diabetic patients. Clin Endocrinol. 2006;65(5):593-597. Available from: https://dx.doi.org/10.1111/j.1365-2265.2006.02633.x.

2. Sugden JA, Davies JI, Witham MD. Vitamin D improves endothelial function in patients with type 2 diabetes mellitus and low vitamin D levels. Diabet Med. 2008;25:320-325.

3. van Etten E, Mathieu C. Immunoregulation by $1,25-$ dihydroxyvitamin D3: Basic concepts. J Steroid Biochem Mol Biol. 2005;97(1-2):93-101. Available from: https://dx.doi.org/ 10.1016/j.jsbmb.2005.06.002.

4. Lai H, Fishman EK, Gerstenblith G, Brinker JA, Tong W, Bhatia $\mathrm{S}$, et al. Vitamin D deficiency is associated with significant coronary stenoses in asymptomatic African American chronic cocaine users. Int J Cardiol. 2012;158(2):211-216. Available from: https://dx.doi.org/10.1016/j.ijcard.2011.01.032. 
5. Tarcin O, Yavuz DG, Ozben B, Telli A, Ogunc AV, Yuksel $\mathrm{M}$, et al. Effect of Vitamin D Deficiency and Replacement on Endothelial Function in Asymptomatic Subjects. J Clin Endocrinol Metab. 2009;94(10):4023-4030. Available from: https://dx.doi.org/10.1210/jc.2008-1212.

6. Pilz S, Dobnig H, Fischer JE, Wellnitz B, Seelhorst U, Boehm BO, et al. Low Vitamin D Levels Predict Stroke in Patients Referred to Coronary Angiography. Stroke. 2008;39(9):26112613. Available from: https://dx.doi.org/10.1161/strokeaha. 107.513655 .

7. Reis JP, von Mühlen D, Michos ED, Miller ER, Appel LJ, Araneta MR, et al. Serum vitamin D, parathyroid hormone levels, and carotid atherosclerosis. Atherosclerosis. 2009;207(2):585-590. Available from: https://dx.doi.org/10. 1016/j.atherosclerosis.2009.05.030.

8. Chitalia N, Recio-Mayoral A, Kaski JC, Banerjee D. Vitamin D deficiency and endothelial dysfunction in nondialysis chronic kidney disease patients. Atherosclerosis. 2012;220(1):265-268. Available from: https://dx.doi.org/10. 1016/j.atherosclerosis.2011.10.023.

9. Khazai N, Judd SE, Tangpricha V. Calcium and vitamin D: Skeletal and extraskeletal health. Curr Rheumatol Rep. 2008;10(2):110-117. Available from: https://dx.doi.org/10. 1007/s11926-008-0020-y.

10. Tarçın O, Yavuz DG, Özben B, Telli A, Öğünç AV, Yüksel M. Effect of vitamin D deficiency and replacement on endothelial function in asymptomatic subjects. J Clin Endocrinol Metab. 2009;94:4023-4053.

11. Akin F, Ayça B, Köse N, Duran M, Sarı M, Uysal OK, et al. Serum Vitamin D Levels Are Independently Associated With Severity of Coronary Artery Disease. J Invest Med. 2012;60(6):869-873. Available from: https://dx.doi.org/10. 2310/jim.0b013e31825457cb.

12. Baktır AO, Dogan Y, Sarlı B, Sahin O, Demirci E, Akpek $\mathrm{M}$, et al. Relationship between serum 25-hydroxyvitamin D levels and the SYNTAX score in patients with acute coronary syndrome. Anatolian J Cardiol. 2017;17(4):293-293.

Copyright: (C) the author(s), 2020. It is an open-access article distributed under the terms of the Creative Commons Attribution License (CC BY 4.0), which permits authors to retain ownership of the copyright for their content, and allow anyone to download, reuse, reprint, modify, distribute and/or copy the content as long as the original authors and source are cited.

How to cite this article: Shaik RBS, Madhumitha R. Assessment of Correlation of Vitamin D Level with Coronary Artery Disease. Acad. J Med. 2020;3(1):70-73.

DOI: dx.doi.org/10.47008/ajm.2020.3.1.14

Source of Support: Nil, Conflict of Interest: None declared. 